\title{
СУЛЬФИДНЫЕ МЕДНО-НИКЕЛЕВЫЕ МЕСТОРОЖДЕНИЯ В СРЕДИННЫХ МАССИВАХ ПИРЕНЕЙСКОГО ПОЛУОСТРОВА И КАМЧАТКИ
}

\author{
Степанов В. А., Кунгурова В. Е. \\ ФГБУН Научно-исследовательский геотехнологический иентр ДВО РАН, \\ 2. Петропавловск-Камчатский \\ E-mail: vitstepanov@yandex.ru,kunwe@yandex.ru
}

\begin{abstract}
Приведено сравнительное описание двух сульфидных медно-никелевых месторождений, приуроченных к срединным массивам, - Агуабланка (Иберийский массив, Испания) и Шануч (Камчатский массив, Россия), освещены их характерные особенности. Показано, что оба месторождения пространственно и генетически связаны с малыми интрузиями и дайками преимущественно основного состава. Рудные тела имеют линзовидную, воронко-, штокои жилообразную форму и значительную протяженность на глубину. Сульфидные медноникелевые руды месторождений как богатые, так и относительно бедные, текстура руд преимущественно брекчиевая или массивная, реже вкрапленная. В состав рудных минералов входят пирротин, пентландит и халькопирит с незначительной примесью минералов элементов платиновой группы и золота. Над рудными телами располагалась «железная шляпа», являвшаяся основным признаком медно-никелевого оруденения на глубине.
\end{abstract}

Ключевые слова: месторождения Агуабланка, Шануч, сульфидные медно-никелевые руды, платиноиды, золото, мафит-ультрамафиты.

DOI: $10.34078 / 1814-0998-2021-2-17-30$

\section{ВВЕДЕНИЕ}

Сульфидные медно-никелевые месторождения являются основными поставщиками не только никеля, меди и кобальта, но и благородных металлов, в первую очередь палладия, платины и золота. Чаще всего эти месторождения располагаются на краю древних платформ - Норильск, Печенга (Россия), Садбери, Войсис Бей (Канада), Джинчуань (Китай), Камбалда (Австралия) и др. Но некоторые расположены в пределах срединных массивов. Поскольку их металлогения значительно отличается от металлогении складчатых областей и окраин платформ, то и медноникелевые месторождения срединных массивов, вероятно, имеют характерные особенности. В статье рассмотрены геологическое строение и состав руд двух медно-никелевых месторождений, расположенных в Иберийском и Камчатском срединных массивах на западной и восточной окраинах Евро-Азиатского континента.

\section{ИБЕРИЙСКИЙ СРЕДИННЫЙ МАССИВ}

Иберийский срединный массив занимает почти всю Португалию, а также северо-западные и центральные районы Испании. Массив имеет от-

(C) Степанов В. А., Кунгурова В. Е., 2021 четливо выраженный докембрийский цоколь. Он сложен кристаллическими сланцами и гнейсами с прослоями мраморов, кварцитов и амфиболитов. Цоколь перекрыт отложениями, возраст которых варьирует от кембрия до перми. С юга и востока массив обрамлен палеозойскими складчатыми сооружениями. Влияние складчатости выражено в наличии в пределах массива прогибов, выполненных отложениями палеозоя. В герцинское время произошло внедрение интрузивных массивов основного и ультраосновного состава. В мезозое в процессе автономной активизации были сформированы интрузии двуслюдяных гранитов и гранит-порфиров (Щеглов, 1971).

В пределах срединного массива установлены три главных этапа рудообразования. В докембрийском фундаменте массива известны осадочно-метаморфические месторождения железа. В связи с развитием смежных складчатых систем палеозоя формируются вулканогенно-осадочные и осадочные концентрации железа и марганца; с тоналитовыми интрузиями связано появление скарновых железорудных месторождений. В габброноритовом массиве Агуабланка раннего карбона расположено сульфидное медно-никелевое оруденение. Процессы тектоно-магматической активизации в мезозое и кайнозое привели к фор- 
мированию широкого спектра гидротермальных рудных образований. На западном фланге массива в гранитоидных интрузиях находятся крупные месторождения вольфрама и олова. Они представлены сериями кварцевых жил, сопровождаемых грейзеновыми оторочками. Для некоторых вольфрамовых месторождений (Панаскейра) характерно присутствие золота. Иногда золото образует самостоятельные жильные золотокварцевые месторождения с арсенопиритом. Месторождения урана представлены двумя типами. В месторождениях Испании урановая минерализация ассоциирует с медной, кобальтовой и никелевой (месторождения Альбукерк, Ла-Вирхен). В Португалии урановая минерализация является эпитермальной и содержится в жилах халцедоновидного кварца. Изотопный возраст месторождений определяется в 100 млн лет. К альпийским по возрасту в Португалии относятся эпитермальные месторождения полиметаллов, сурьмы и барита. На севере массива известны месторождения флюорита, которые локализуются в известняках лейаса. На юге, в краевой части массива, среди пород раннего палеозоя находятся крупнейшее в мире ртутное месторождение Альмаден, а также сурьмяные месторождения округа Сьюдад-Реаль (Щеглов, 1971).

Месторождение Агуабланка. Сульфидное медно-никелевое месторождение Агуабланка расположено в юго-западной части Иберийского массива. Сульфидная минерализация впервые была открыта в 1993 г. при заверке геохимической аномалии, связанной с «железной шляпой», образованной в результате окисления сульфидных руд. В 2001 г. месторождение приобрела компания Rio Narcea Gold Mines Limited. Запасы месторождения составили 15.7 млн т руды со средним содержанием (мас. \%): никеля - 0.66, меди -0.46 , т. е. около 100 тыс. т никеля и 70 тыс. т меди. Содержания металлов платиновой группы (МПГ) 0.47 г/т, Au - 0.13 г/т. Эксплуатация месторождения началась в 2004 г. (Pina et al., 2006).

Месторождение приурочено к изометричной в плане интрузии Агуабланка площадью около 3 км² $^{2}$ Она сложена преимущественно роговообманковыми габброноритами. Кроме них, в северной части интрузии встречаются пироксениты и перидотиты, а в южной - кварцевые диориты. Массив Агуабланка внедрился вдоль контакта между известняками нижнего кембрия и интрузии Санта Олалла, сложенной тоналитами и гранодиоритами (рис. 1). Изотопный возраст Санта Олаллы оценивается в $341 \pm 3$ млн лет (Ortega et al., 2004).

Габбронорит рудоносной интрузии содержит переменные количества ортопироксена (27-48\%), плагиоклаза (23-47 \%), клинопироксена (4$11 \%)$, амфибола (10-21\%) и небольшую примесь кварца $(<1 \%)$. Большинство пород интрузии не содержит $\mathrm{Fe}-\mathrm{Ni}-\mathrm{Cu}$ сульфидов, за исключением контактов с ксенолитами частично контаминированных вмещающих пород. Постмагматические гидротермальные процессы привели к образованию вторичных минералов - актинолита, хлорита, бастита, талька, карбонатов, серпентина, альбита, серицита и эпидот-цоизита (Ortega et al., 2004; Pina et al., 2006). Изотопный возраст интрузии Агуабланка, определенный U-Pb методом по цирконам, составляет $338.6 \pm 0.8$ млн лет (Romeo et al., 2004), a Ar-Ar методом по флогопитам $-338 \pm 3$ млн лет (Tornos et al., 2004), что отвечает раннему карбону.

Месторождение расположено недалеко от северной границы массива Агуабланка. Медно-никелевое оруgabbronorite, 4 - mineralized rocks, 5 - fault, 6 - section cross 
денение слабо выражено на поверхности, но хорошо развито от нескольких метров ниже поверхности до глубины более 600 м. На поверхности сульфидные руды окислены и образуют «железную шляпу» мощностью 8-10 м. Оруденение представлено двумя субвертикальными телами с переменным количеством сульфидов от 10 до $80 \%$. Основное рудное тело сложено богатыми брекчиевыми рудами, окруженными более бедными вкрапленными. Оно имеет форму субвертикальной воронки с наклоном $70-80^{\circ}$ в северных румбах. Ширина рудного тела от 250-300 м по меридиану до 600 м в широтном направлении, оно прослежено на глубину более 600 м (рис. 2). Расположенное к северу от него второе рудное тело меньше по размеру и сложено вкрапленными рудами.

Богатая сульфидная $\mathrm{Ni}-\mathrm{Cu}$ минерализация основного рудного тела тесно связана с магматическими брекчиями. Брекчия состоит из матрицы роговообманкового и флогопитсодержащего габбронорита, содержащего медно-никелевые сульфиды. В ней находятся обильные обломки безрудных или слабо минерализованных мафитультрамафитных пород (рис. 3).

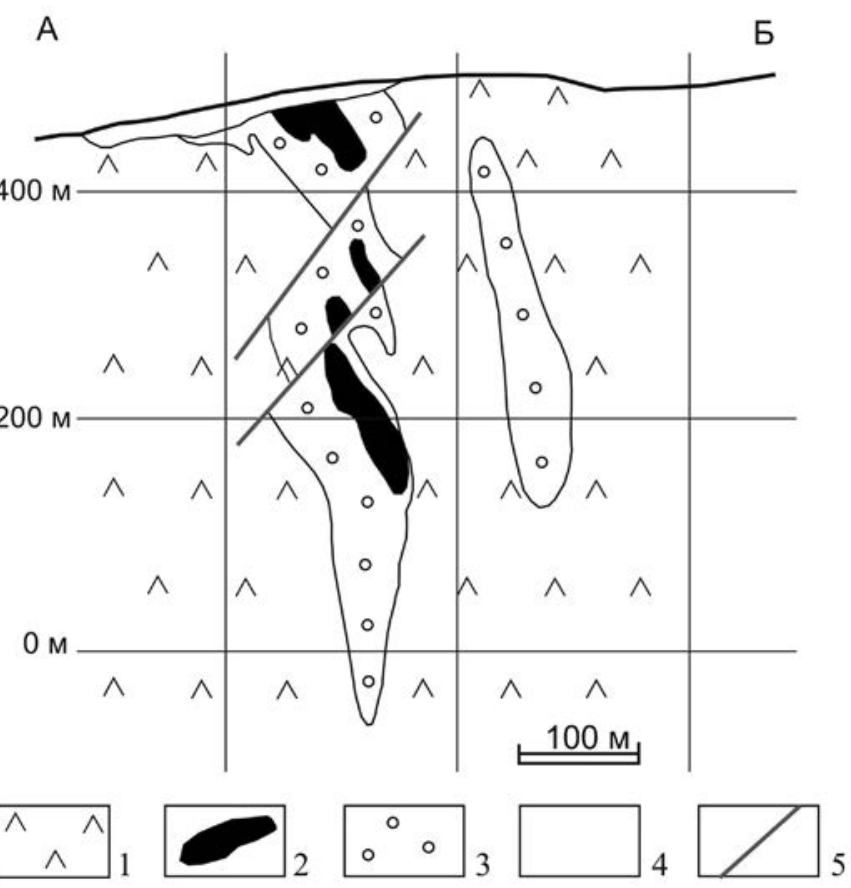

Puc. 2. Геологический разрез рудных тел по линии А Б (см. рис. 1): 1 - габбронориты, 2 - массивные руды, 3 вкрапленные руды, 4 - «железная шляпа», 5 - разломы

Fig. 2. Geological section of ore bodies along the A - Б line (Fig. 1): 1 -gabbronorite, 2 - massive ores, 3 - disseminated ores, 4 - "iron hat", 5 - faults
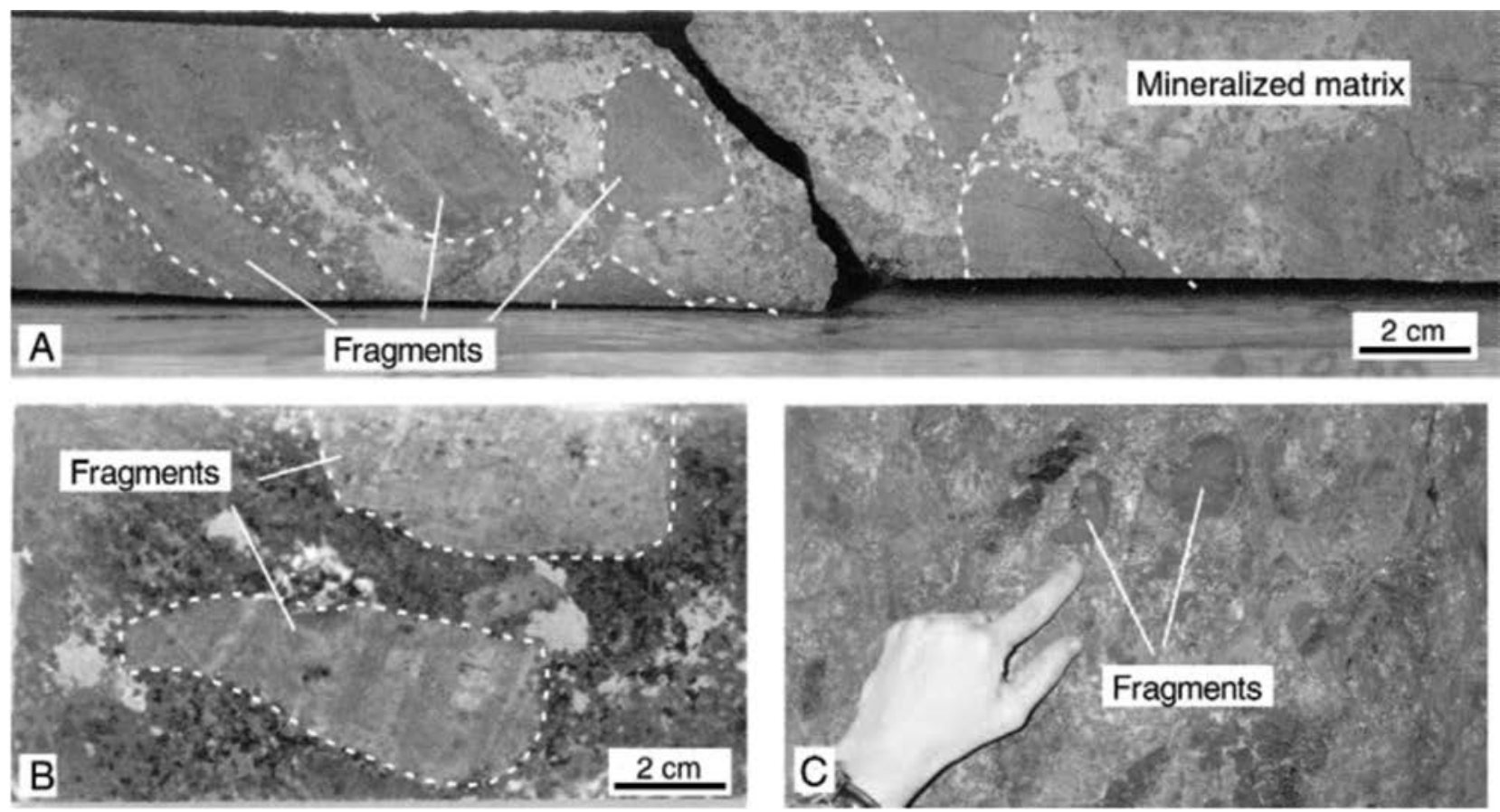

Puc. 3. Рудоносные брекчии месторождения Агуабланка (Pina et al., 2006): A, В - фотографии керна рудоносных брекчий. Обломки безрудных мафических пород в матрице, содержащей массивные (А) и рассеянные (B) сульфиды; C - рудоносная брекчия из подземной выработки. Фрагменты безрудных пород в минерализованной матрице

Fig. 3. Ore-bearing breccias (Pina et al., 2006): A, B - photographs of drill core ore-bearing breccias. Barren mafic rock fragments in a matrix containing massive (A) and disseminated (B) sulfides; C - ore-bearing breccia from underground works. Fragments of barren rocks in a mineralized matrix 

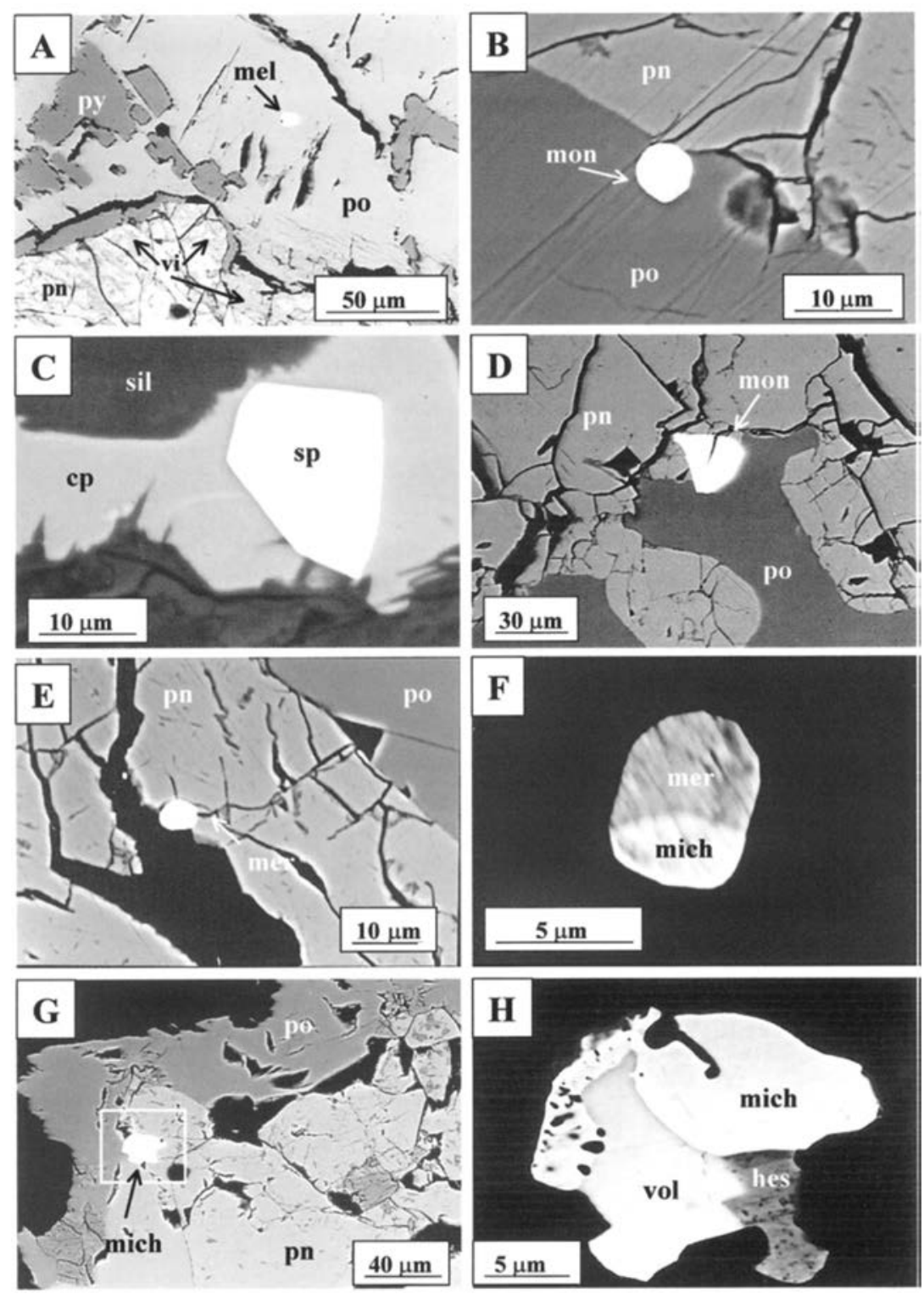

Puc. 4. Минералы платиновой группы в обратнорассеянных электронах (Ortega et al., 2004): А - мелонит в составе пирротина в массивной руде; В - гипидиоморфный мончеит в пирротине на контакте с пентландитом в массивной руде; C - гипидиоморфный сперрилит внутри халькопирита во вкрапленной руде; D - мончеит неправильной формы на контакте пирротина и пентландита; E - Pt-несущий меренскит на краю пентландита в массивой руде; F - композитное зерно меренскита и майченерита в пирротине, массивная руда; G - составное зерно майченерита и теллуридов в пентландите на контакте с пирротином; Н - деталь этого композитного зерна, содержащая майченерит, волынскит и гессит

Fig. 4. Back-scattered electron images of platinum group minerals (Ortega et al., 2004): A - melonite within pyrrhotite in the massive ore; B subhedral moncheite in pyrrhotite in contact with pentlandite, massive ore; $\mathrm{C}$ - subhedral sperrylite within chalcopyrite, disseminated ore; D - irregularly shaped moncheite at the contact between pyrrhotite and pentlandite; E - Pt-bearing merenskyite at the edge of pentlandite, massive ore; $\mathrm{F}$ composite grain of merenskyite and michenerite in pyrrhotite, massive ore; $\mathrm{G}$ - composite grain of michenerite and tellurides in pentlandite at the contact with pyrrhotite; $\mathrm{H}$ - detail of this composite grain containing michenerite, volynskite, and hessite
Обломки имеют округлые полуокатанные края и резкие контакты с минерализованной матрицей. Размер их от нескольких до 8 см. Они, как правило, не взаимодействуют с сульфидсодержащей матрицей.

Исключением являются некоторые фрагменты дунита, имеющие на краях обломков реакционные ободки с более высокой концентрацией таких водосодержащих минералов, как хлорит, амфибол и серпентин. Обломки обычно состоят из одной породы. Чаще всего встречаются габбро, роговообманковые габбро и габбронориты, реже перидотиты, дуниты, гарцбургиты, верлиты, анортозиты и пироксениты. Фрагменты пород мелко- и среднезернистые с типичной кумулятивной структурой. Основные нерудные минералы представлены оливином, ортопироксеном, клинопироксеном, плагиоклазом, амфиболом и флогопитом. Среди рудных минералов отмечаются шпинель, магнетит, ильменит и $\mathrm{Fe}-\mathrm{Ni}-\mathrm{Cu}$ сульфиды.

Сульфиды в матрице образуют вкрапленность и массивные скопления. Содержание их меняется от 20 до 85 \%. Наиболее богатая сульфидами руда имеет леопардовую текстуру. Ее образуют идиоморфные кристаллы пироксена, оливина или плагиоклаза, заключенные в сульфидную массу желтоватого цвета. В более распространенной бедной руде сульфиды встречаются в виде полиминеральных агрегатов с различным размером зерен. Богатая руда с леопардовой текстурой встречается в ядре тела брекчии. Она окружена бедной рудой с вкрапленной текстурой и обильными фрагментами мафических пород. Габбронориты с рассеянной вкрапленностью сульфидов постепенно переходят в безрудные разности, содержащие некоторое количество обломков 
мафитовых пород. Внутри фрагментов сульфиды могут встречаться в виде редкой вкрапленности или прожилков халькопирита.

При минералогическом изучении руд были выделены два минеральных комплекса: магматический и гидротермальный (Ortega et al., 2004).

В магматическом комплексе главными рудными минералами являются пирротин, пентландит и халькопирит с примесью минералов элементов платиновой группы (меренскит, майченерит, палладийсодержащий мелонит, мончеит, ирарсит и сперрилит). Кроме них отмечаются магнетит, ильменит, виоларит, марказит, теллуриды серебра (теллуровисмутит, волынскит и гессит) и самородное золото. Вкрапленная руда содержит несколько больше халькопирита, чем брекчиевая. Платиноиды в основном связаны с сульфидами, в первую очередь пентландитом и пирротином, в меньшей степени с халькопиритом (см. рис. 4). В гидротермальный этап отлагался пирит нескольких генераций.

В верхней части месторождения, в зоне окисления («железной шляпе») развита ассоциация окисленных минералов: гарниерит, гетит, малахит. Из минералов благородных металлов в ней обнаружены теллуровисмутит, сперрилит, а также оксиды минералов платиновой группы.

\section{КАМЧАТСКИЙ СРЕДИННЫЙ МАССИВ}

Камчатский срединный массив (КСМ) расположен в южной части Камчатского полуострова. Он представляет собой плитообразное тело, вытянутое в меридиональном направлении на 260 км при ширине около 50-60 км. Это крупный выступ протерозойских, палеозойских и мезозойских (доверхнемеловых) образований (Трухин и др., 2008). КСМ полностью отвечает критериям срединного массива в понимании А. Л. Яншина (Яншин, 1965), А. Д. Щеглова (Щеглов, 1971) и других исследователей. Камчатский срединный массив отмечается в ряде работ как Срединный Камчатский массив, Срединный Камчатский выступ, Центрально-Камчатский кристаллический массив или Срединно-Камчатский горст-антиклинорий (Тарарин, 1986; Виноградов, 1994; Полетаев, 1999; Вильданова и др., 2002; Некрасов, 2003). В работе А. И. Ханчука доказывается двухэтажное строение массива. Нижний этаж сложен диафторированными кианитовыми, кордиеритовыми, кордиерит-гиперстеновыми гнейсами и плагиогнейсами со сложной слоистой структурой. На них почти горизонтально залегает прогрессивно метаморфизованный комплекс терригенно-вулканогенных отложений, от- несенный к малкинской серии палеозоя. Это позволило рассматривать Камчатский кристаллический массив как срединный (Ханчук, 1983). О. Б. Селянгин считает, что геологическое строение КСМ, положение интрузивов и происхождение исходной высокомагнезиальной бонинитоподобной магмы лучше согласуются с тектонической природой срединного массива в структуре эпигеосинклинального орогена (Селянгин, 2009).

Древние метаморфические образования колпаковской и камчатской серий фундамента массива приурочены к центральной части массива, а терригенные, сланцевые и вулканогенно-осадочные толщи мелового и палеогенового возраста, слагающие его чехол, - к периферии. В обрамлении массива развиты осадочные палеогеннеогеновые отложения. Стратифицированные образования прорваны интрузиями андриановского метагаббрового комплекса палеозойского возраста; крутогоровского плагиогранитового комплекса нижнего мела; кольского плагиогранит-гранодиоритового комплекса верхнего мела; левоандриановского дунит-клинопироксенит-монцонитового комплекса верхнего мела - палеоцена; базитов и гипербазитов дукукского комплекса палеоцен-эоценового возраста; лавкинского гранодиоритового комплекса миоцена. Наиболее молодые риолиты и риодациты голоцена слагают Хангарское вулканическое сооружение. Срединный массив ограничен с востока Шаромским, а с запада Воровским региональными разломами с характерной для Камчатки меридиональной ориентировкой.

В КСМ выделяются три минерагенические эпохи, совпадающие по времени с формированием крупных интрузивных комплексов: кольского (позднемеловая эпоха), дукукского (палеоцен - эоцен) и лавкинского (миоцен). С позднемеловой эпохой связано формирование оруденения золото-кварцевой и золотосульфидно-кварцевой формации (проявления Крутогоровского, Юртинского и ПорожистоГольцовского узлов). Платиноидно-медно-никелевое оруденение генетически соответствует формированию в позднем палеоцене - раннем эоцене основных - ультраосновных интрузий дукукского комплекса (Шанучский и Кувалорогский узлы). Миоценовая эпоха ознаменовалась становлением проявлений золото-медномолибденовой формации (Хим-Кирганикский и Крутогоровско-Андриановский узлы).

В пределах КСМ известны следующие типы медно-никелевого оруденения: расслоенные материнские интрузии с сингенетичным сульфидным оруденением (относительно крупный Кувалорогский массив с рудопроявлениями Снежное, 
Нижнемедвежье, Верхнемедвежье, Перевальное, Кувалорог, Правокихчинское, Рассоха, Надежда); малые тела мафит-ультрамафитов - сателлиты материнских интрузий, слабо или недифференцированные с сингенетичным сульфидным оруденением (Северное, Озерное, Обвальное, Медвежий мыс, Оленье); дайкообразные тела ультрамафитов с богатым эпигенетическим сульфидным оруденением (рудопроявления Аннабергитовая Щель, Коба). Но наиболее перспективным является находящееся в эксплуатации месторождение Шануч, имеющее сложный генезис. Минеральный состав рудных тел обусловлен тремя процессами: ликвацией расплава, магматической дифференциацией расплава из первичного очага, привносом металлов и перераспределением компонентов руд в процессе постмагматической деятельности, о чем свидетельствует геохимическая неоднородность рудных тел.

Месторождение Шануч. Сульфидное медноникелевое месторождение Шануч находится в северной краевой зоне выступа домезозойских метаморфических пород КСМ, на склоне г. Верхняя Тхонжа, служащей водоразделом между р. Ича и ее притоком р. Шануч (Степанов, Трухин, 2007; Трухин и др., 2009). Это среднее по запасам никеля и меди месторождение, отличающееся богатыми по содержанию никеля преимущественно массивными сульфидными медно-никелевыми рудами с относительно бедными содержаниями элементов платиновой группы.

Район месторождения представлен кристаллическими сланцами и гнейсами камчатской серии. На флангах месторождения они перекрыты метатерригенными образованиями хейванской свиты. Метаморфические толщи прорваны интрузиями крутогоровского комплекса гнейсовидных плагиогранитов и гнейсогранитов, а также интрузиями кольского гранит-плагиогранитного комплекса. Никеленосными являются малые интрузии, дайки и силлы амфиболовых, биотитамфиболовых меладиоритов, габбро, пироксенитов, горнблендитов и кортландитов дукукского комплекса. Главные минералы пород, широко варьирующие в количественных соотношениях, представлены оливином, ортопироксеном, клинопироксеном, куммингтонитом, высокоглиноземистым кальциевым амфиболом ряда паргасит - гастингсит, плагиоклазом (от битовнита до альбита), калиевым полевым шпатом, слюдой ряда флогопит - биотит, кварцем. В качестве акцессориев содержатся ильменит, апатит, глиноземистая шпинель, хромит, альмандин, редко циркон и ортит. Породы подвержены средне-, низкотемпературным вторичным изменениям, которые выражаются в замещении ранних амфиболитов поздни- ми, оталькованию, хлоритизации, окварцеванию, карбонатизации.

По петрохимическим признакам большая часть никеленосных магматических пород месторождения Шануч относится к известковощелочной серии, наиболее мафические попадают в поле толеитовой (Селянгин, 2014). Серия характеризуется нормальной щелочностью и кали-натровым (для части пород - натровым) профилем, с вариациями калиевости от низкой до высокой, прямо коррелирующей с содержанием в породах основного калийсодержащего минерала - флогопита или биотита. Происхождение шанучских ультрамафитов - габброидов - диоритов обеспечивается последовательным фракционированием из исходной высокомагнезиальной магмы минеральных фаз в порядке сверхкотектической (мономинеральной) и котектической (совместной) кристаллизации.

Изотопный возраст никеленосных интрузий в районе месторождения определен $\mathrm{Rb}-\mathrm{Sr}$ методом по мономинеральным фракциям биотита и амфибола в Центре изотопных исследований ВСЕГЕИ (г. Санкт-Петербург). Он равен 49.2 \pm 2.7 млн лет, что отвечает эоцену (Степанов и др., 2007). Интрузии образуют субширотную зону сложноветвящихся, сопряженных дайкоподобных тел. Ширина их от первых до 200 м, при мощности отдельных тел от 10 до 100 м. Падение к югу под углами от 40 до $85^{\circ}$. К центральной части этой зоны приурочено месторождение Шануч.

Месторождение представлено серией субвертикально ориентированных разобщенных рудных тел, сопряженных с малыми интрузиями неправильной формы и дайками дукукского комплекса, размещение которых контролируется разрывными нарушениями. Руды локализованы как в приконтактовых, так и в других частях сложно дифференцированных рудоносных интрузий. Наблюдается жило-, штокообразная и линзовидная форма рудных тел. Характерной их особенностью является зональное строение. Центральная часть рудных тел, как правило, сложена массивными сульфидными рудами (70$90 \%$ сульфидов) или состоит из сближенных зон с прожилковым, пятнистым или брекчиевидным оруденением. Жилы массивной текстуры зачастую оконтурены зонами брекчиевидных и брекчиевидно-прожилковых руд (30-70 \% сульфидов), сменяющихся к периферии прожилковыми (15-30 \% сульфидов) и вкрапленными (5$15 \%$ сульфидов).

Одним из наиболее изученных является рудное тело № 1 (рис. 5). Оно имеет в горизонтальном сечении сложную, серповидную форму с 


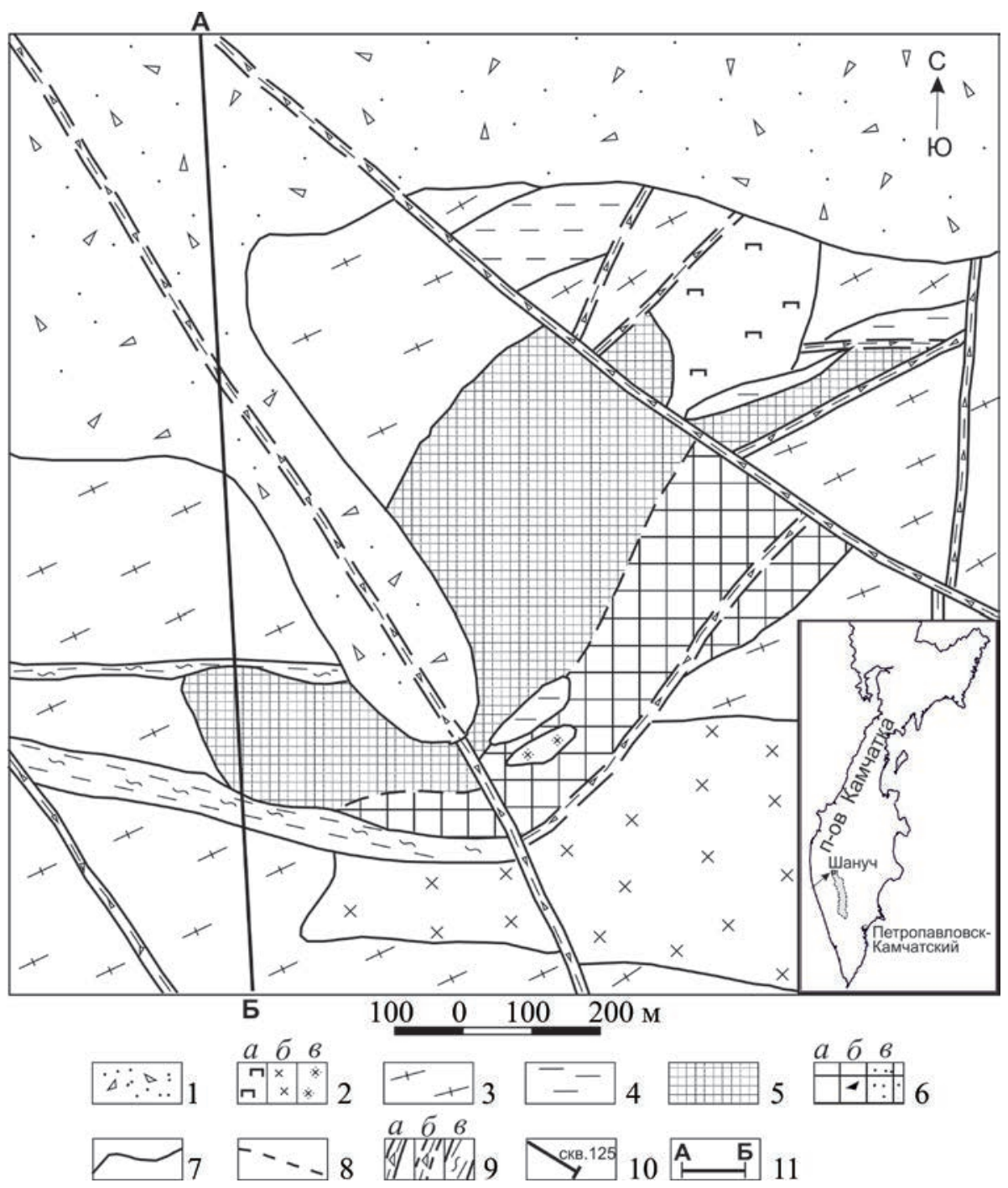

Puc. 5. Схематическая геологическая карта рудного тела № 1 месторождения Шануч (Трухин и др., 2009). Условные обозначения к рис. 5 и 6: 1 - рыхлые четвертичные отложения; 2 - интрузии дукукского комплекса: амфиболовые габбро (a), биотит-амфиболовые меладиориты (б), гранатсодержащие мусковит-биотитовые диориты (в); 3 - крутогоровский гнейсово-плагиогранитовый комплекс: гнейсовидные плагиограниты, гнейсограниты, плагиограниты; 4 - камчатская метаморфическая серия: кристаллические сланцы гранат-ставролитбиотитового состава; 5 - окисленные руды; 6 - сульфидные медно-никелевые руды: массивные $(a)$, брекчиевидные, гнездово-вкрапленные (б), прожилково-вкрапленные и вкрапленные (b); 7 - геологические границы; 8 - границы между типами руд; 9 - зоны дробления: достоверные $(a)$, предполагаемые (б), зоны милонитизации (в); 10 - скважины, по которым отобраны образцы руд, их номера; 11 - линия разреза

Fig. 5. Schematic geological map of orebody No. 1 of the Shanuch deposit (Trukhin et al., 2009). Legend for Fig. 5, 6: 1 - unconsolidated Quaternary deposits; 2 - intrusions of the Dukuk complex: amphibole gabbro (a), biotiteamphibole meladiorites (б), garnet-bearing muscovite-biotite diorites (в); 3 -Krutogorov gneiss-plagiogranite complex: gneiss-like plagiogranites, gneiss granites, plagiogranites; 4 - Kamchatka metamorphic series: crystalline schists of garnet-staurolite-biotite composition; 5 - oxidized ores; 6 - sulfide copper-nickel ores: massive (a), brecciated, pocketdisseminated (б), vein-disseminated and disseminated (в); 7 - geological boundaries; 8 - boundaries between ores types; 9 - crush zones: proven $(a)$, assumed $(\sigma)$, mylonitization zones $(b) ; 10$ - wells of ore sampling with numbers; 11 - section line

размерами $120 \times 50$ м и прослежено на глубину более 300 м. Рудное тело в целом повторяет контур материнского интрузива, который на глубине 125-375 м от поверхности имеет раздув мощности до 90 м. В краевых частях отмечаются ксенолиты измененных оруденелых кристаллических сланцев с прожилковой и вкрапленной сульфидной минерализацией. Контакты интрузивных пород с вмещающими гранитогнейсами четкие, резкие, нередко тектонические.

В вертикальном разрезе (рис. 6) рудное тело линзовидное, с раздувом в центральной части. 


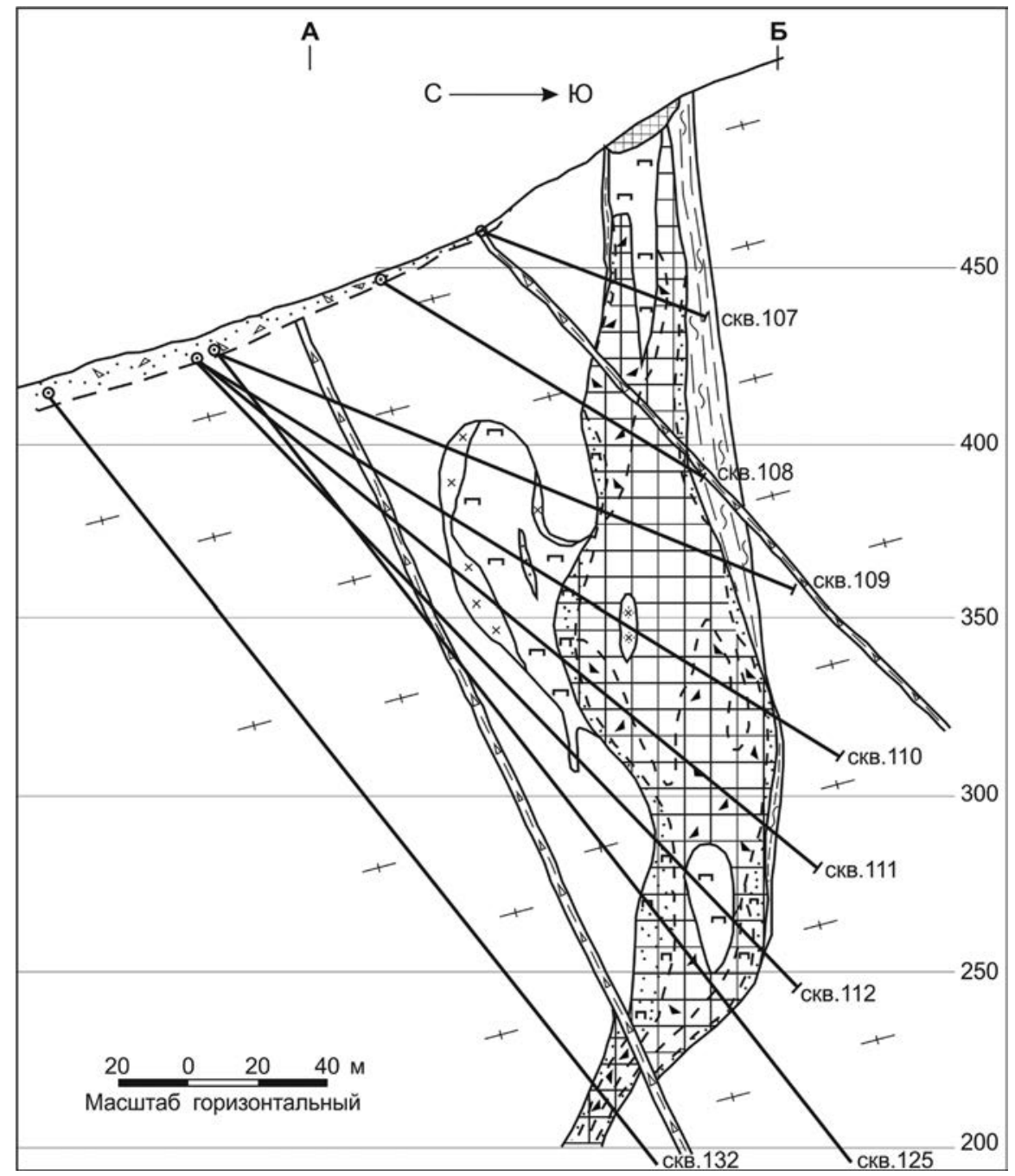

Puc. 6. Схематический разрез по рудному телу № 1 месторождения Шануч. Условные обозначения на рис. 5

Fig. 6. Schematic section of orebody No. 1 at the Shanuch deposit. For Legend, see Fig. 5

Общая мощность оруденелых зон, входящих в состав рудного тела № 1 , колеблется от 1.4 до 53.9 м (совместно с включенными маломощными безрудными интервалами).

В состав рудных минералов входят, главным образом, пирротин, пентландит и халькопирит. Вариации их количественных соотношений незначительны, но пирротин резко преобладает над другими рудными минералами. Менее развиты виоларит, пирит; присутствуют сфалерит, редкие борнит, халькозин, ковеллин, линнеит, зигенит, маккинавит, полидимит, миллерит, молибденит, леллингит, кобальтин, брейгауптит, ульманит и мелонит, теллуриды висмута, галенит, герсдорфит, никелин, самородное золото, ирарсит (рис. 7), сперрилит, котульскит, майченерит и изоферроплатина. Руды характеризуются однотипными минеральными ассоциациями, среди которых можно выделить пентландитпирротиновую, магнетит-халькопиритовую и пирит-марказитовую. Две первые являются рудоносными (Степанов и др., 2010).

Среднее содержание полезных компонентов в целом по рудному телу № 1 составляет, мас. \%: никеля -5.41 , меди -0.85 , золота -0.24 , палладия -0.40 , платины -0.13 г/т. Наибольшие средние содержания промышленно ценных компонентов наблюдаются в массивных рудах, \%: Ni - 7.58, Cu - 1.10, Co - 0.19, Au 0.32 г/т, $\mathrm{Pd}-0.53$ г/т, $\mathrm{Pt}-0.16$ г/т. В брекчиевидных рудах средние содержания, по сравнению с массивными, несколько снижаются. Прожилково-вкрапленные руды характеризуются еще меньшими концентрациями никеля, меди, кобальта, платиноидов. Никель-медное отношение остается почти одинаковым (6-6.9) во всех типах руд, кроме вкрапленных (2.8), а палладий-платиновое несколько уменьшается от 3.3 в массивных рудах до 2.6 в прожилкововкрапленных. Наименьшие концентрации по- 

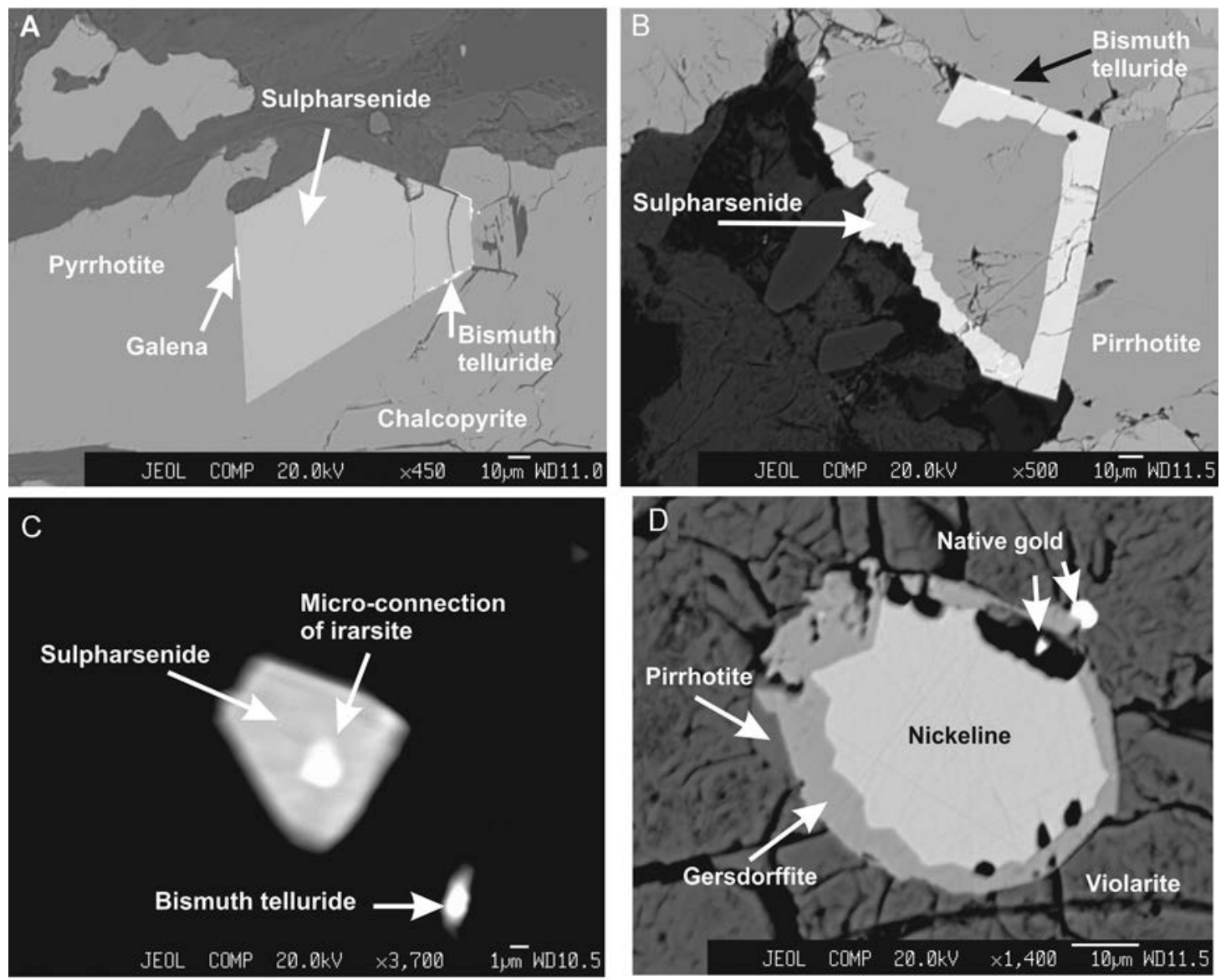

Puc. 7. Взаимоотношения минералов в руде месторождения Шануч (в отраженных электронах) (Степанов и др., 2010): А - идиоморфный кристалл диарсенида (светло-серое) на контакте моноклинного пирротина и халькопирита (серое) с породообразующими минералами (темно-серое); вдоль границы диарсенида наблюдаются микровключения теллуридов висмута (белое) (обр. 110-37); В - скелетные кристаллы диарсенида (белое) по границе зерен гексагонального пирротина (серое), пентландита (светло-серое) и породообразующих минералов (темно-серое) (обр. 110-34); С - в пирротине (черное) идиоморфный кристалл диарсенида (серое) с изометричным микровключением ирарсита (обр. 110-22); D - замещенное герсдорфитом (серое) идиоморфное зерно никелина (светло-серое) среди виоларита (темно-серое), заместившего пентландит; по границам зерен и в пустотках выщелачивания (черное) наблюдаются микровключения самородного золота (белое) (обр. 110-19)

Fig. 7. Mineral relationships in the Shanuch deposit ore (in reflected electrons) (Stepanov et al., 2010): A - idiomorphic diarsenide crystal (light gray) at the contact of monoclinal pyrrhotite and chalcopyrite (gray) with rock-forming minerals (dark gray); microinclusions of bismuth tellurides (white) observed along the diarsenide boundary (samples 11037); B - skeletal crystals of diarsenide (white) along the grain boundary of hexagonal pyrrhotite (gray), pentlandite (light gray) and rock-forming minerals (dark gray) (samples 110-34); $\mathrm{C}$ - in pyrrhotite (black), an idiomorphic diarsenide crystal (gray) with an isometric microinclusion of irarsite (samples 110-22); D - idiomorphic nickeline grain (light gray) replaced by hersdorffite (gray) among violarite (dark gray), which replaced pentlandite; along the grains boundaries and in leaching blebs (black), microinclusions of native gold (white) are observed (samples 110-19)

лезных компонентов содержат вкрапленные руды, мас. \%: никеля - 0.33, меди -0.12 , кобальта - 0.01. Сумма платиноидов уменьшается до 0.05 г/т, золота - до 0.1 г/т, отношение никеля к меди - до 2.8, а палладия к платине до 1.5 .

Массивные сульфидные руды. Во многих образцах массивных руд наблюдаются изометрические и удлиненные обломки вмещающих пород. Обломки вмещающих магматитов представлены мелко-, среднезернистыми биотитамфиболовыми меладиоритами с тонкими лин- зовидными сульфидными прожилками и оруденелыми апопироксенитовыми, апоталькитовыми плагиоклаз-кварц-флогопитовыми амфиболитами, зацементироваными в рудном силикатносульфидном материале.

На периферии обломки корродированы, а пустоты заполнены силикатами и сульфидами. Промежутки между кристаллами амфиболов, находящихся в приконтактовой зоне измененных пород, выполнены халькопиритом и пирротином. По контуру обломков пород развиты тонкие магнетитовые оторочки и линейные пустотки, сви- 
детельствующие, по-видимому, о реакционном воздействии на породу сульфидного расплава. В сульфидном материале на границе с обломками породы наблюдаются многочисленные округлые мелкие зерна магнетита.

На месторождении преобладают массивные халькопирит-пентландит-пирротиновые руды, сложенные пирротином, содержание которого колеблется от 40 до 90 \%. Он представлен крупными (до 1.5 мм) изометрическими, таблитчатыми и октаэдрическими кристаллами свежего облика. В кристаллах пирротина наблюдаются линзовидные и пламеневидные выделения пентландита II. Менее широко развит пентландит, количество которого в руде составляет 10-45 \%.

Выделения пентландита I состоят из крупных (до 1 мм) эвгедральных и субгедральных кристаллов. В периферических зонах выделений пентландита размер зерен минерала уменьшается (до 0.10.2 мм), а расположенные между зернами пирротина апофизы выделений пентландита состоят из еще более мелких (0.0 n мм) изометрических и ксеноморфных зерен. В периферических частях кристаллов пирротина и пентландита наблюдается отложение прожилковидных выделений виоларита II. Содержание халькопирита колеблется от 2 до $15 \%$. Халькопирит представлен ксеноморфными выделениями, выполняющими интерстиции между зонами пентландита I и пирротина. В пентландите I развиты оторочки виоларита. Пирит встречается от единичных зерен до $5 \%$. Из редко наблюдаемых минералов - герсдорфит, никелин, единичны эмульсионные включения (<0.001 мм)

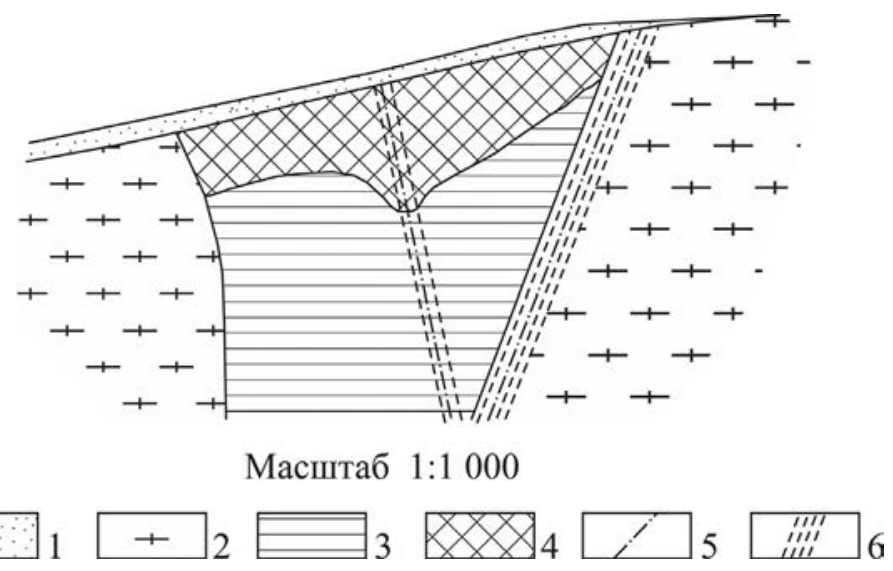

Рuc. 8. Схематический разрез зоны окисления рудного тела № 1 (Кунгурова и др., 2016): 1 - почвенно-растительный слой, 2 гранито-гнейсы, 3 - первичные медно-никелевые руды, 4 - окисленные руды, 5 - тектонические нарушения, 6 - зоны дробления и трещиноватости

Fig. 8. Schematic section of the oxidation zone of orebody No. 1 (Kungurova et al., 2016): 1 - top soil, 2 - granite-gneisses, 3 - primary copper-nickel ores, 4 - oxidized ores, 5 - tectonic disturbances, 6 crush and jointing zones ирарсита в сульфоарсенидах и пентландите, теллуриды висмута в пирротине, халькопирите.

Брекчиевидные и гнездовидно-вкрапленные руды, как правило, оконтуривают массивные. Характерной особенностью руд является более значительное, чем в массивных, присутствие обломков меладиоритов, часто изометрической формы, изогнутых, скрученных, развальцованных, заключенных в рудной массе. Рудный материал цементирует обломки. Основным рудным минералом является пирротин (пирит-виоларит-пирротиновые, халькопирит-виоларит-пирротиновые, халькопирит-пирротин-виоларитовые руды), пирит (халькопирит-виоларит-пиритовые, виоларит-пиритовые руды), халькопирит (виоларит-пирротинхалькопиритовые) или виоларит (халькопиритпирротин-виоларитовые и пирит-пирротин-халькопирит-виоларитовые руды). Отмечается присутствие теллуридов висмута, галенита, герсдорфита, никелина, самородного золота.

Вкрапленные и прожилковые руды. Краевые зоны рудного тела № 1 представлены вкрапленными, пятнисто-вкрапленными, прожилковыми и пятнисто-прожилковыми рудами с содержанием сульфидов от 5 до 30 \%. В зальбандах рудных тел наблюдается изменение вмещающих пород и развитие в них линейно вытянутых сульфидно-силикатных полосчатых образований. Наблюдаются многочисленные апофизы и прожилки сульфидного материала, импрегованного в кавернозные и трещиноватые участки вмещающей породы. Минеральный состав рассматриваемых руд неоднороден: нередко руда представлена полностью пиритом или халькопиритом. Содержание виоларита в рудах колеблется от 0 до $20 \%$, пирротина - до $40 \%$. В пиритовой и пирротинсодержащей руде на границе силикатного и сульфидного материалов наблюдается смятие зерен пирита. Это может свидетельствовать о том, что внедрившийся сульфидный расплав был, вероятно, вязкой консистенции. Часть зерен пирротина сдвойникована, что является признаком кристаллизации минерала в условиях сжатия. Образование концентрически-зональных, крустификационных и колломорфных структур на участках развития выделений пирита I указывает на вероятное гидротермальное происхождение минералов. Выделения виоларита I, заполняющие промежутки между срастаниями пирита I, по-видимому, также образовались из растворов. Виоларит I местами заме- 
щен виоларитом II. Выделения халькопирита выполняют интерстиции между обособлениями пирита I и виоларита I.

В приповерхностной части рудного тела № 1 находится зона окисления, в пределах которой сульфидные медно-никелевые руды окислены и выщелочены с образованием «железной шляпы» (рис. 8). Мощность ее колеблется от 0.5 до 9.6 м, в среднем составляя 4.6 м. В обнажениях верхняя часть зоны окисления представляет собой «пористые структурные лимониты» яркого красно-желтого и буро-желтого цвета. Зона окисления характеризуется большим разнообразием минерального состава (Кунгурова и др., 2016). Здесь встречены, помимо преобладающего лимонита, лепидокрокит, гетит, марказит, гарниерит, борнит, ковеллин, халькозин, аннабергит, ярозит, нонтронит, моренозит, ретгерсит, азурит, малахит; редко бравоит, виоларит, рутил, циркон, золото, единичные кристаллы сперрилита. Золото находится в виде зерен размером 0.10.15 мм, сперрилит - в виде кристалла в шлихе и микровростка в герсдорфите. Из числа породообразующих минералов в зоне окисления встречены: полевые шпаты, кварц, опал, каолинит, халцедон, амфиболы, пироксены, роговая обманка, биотит.

Содержание никеля (0.03\%), меди $(0.6 \%)$ и кобальта $(0.01 \%)$ в окисленных рудах значительно ниже, чем в первичных. Активнее выщелачиваются никель и кобальт, меньше - медь. Содержание благородных металлов в окисленных рудах на порядок выше, чем в первичных, и составляет, г/т: платины -3.09 , палладия -2.43 , золота -2.07 .

\section{ОБСУЖДЕНИЕ РЕЗУЛЬТАТОВ}

Рассматриваемые сульфидные медно-никелевые месторождения являются средними по запасам никеля. Они не относятся к крупным пластовым или стратиформным медно-никелевым месторождениям, приуроченным к дифференцированным ультрамафит-мафитовым интрузиям (Бушвельд, Стиллуотер, Садбери, Норильск и др.), а ассоциируют со сравнительно мелкими интрузиями и дайками преимущественно основного состава. Месторождение Шануч генетически связано со становлением малых интрузий и даек меладиоритов и габбро, а Агуабланка - с небольшой интрузией габброноритов.

На обоих месторождениях основные рудные тела ориентированы субвертикально и имеют трубчатую или воронкообразную форму с расширением по восстанию рудоносной структуры. Площадь выхода рудных тел на дневную поверхность невелика, что усложняет их поиски. Для обоих месторождений типична зона окисления в виде «железной шляпы», которая послужила основным поисковым признаком наличия месторождения на глубине.

Наблюдается однотипная зональность рудных тел на обоих месторождениях - массивные и брекчиевые наиболее богатые руды, расположенные в центральной приосевой части рудных тел, сменяются бедными вкрапленными рудами на периферии. Массивные руды обогащены никелем, тогда как содержание его в брекчиевидной, прожилковой и вкрапленной весьма неустойчиво и колеблется в широком диапазоне.

Основные рудные минералы типичны для всех других сульфидных медно-никелевых месторождений. Это пирротин, халькопирит и пентландит с примесью минералов благородных металлов, главным образом палладия, платины и золота. Мелкие зерна висмутита, галенита и сульфоарсенидов кобальтит-герсдорфитового состава встречаются в пирротине и пентландите. Вкрапленные руды обычно содержат больше халькопирита, чем массивные. Для пиритсодержащих руд характерно большое разнообразие текстур.

Руды как богатые (месторождение Шануч), так и более бедные (Агуабланка). Относительная бедность месторождения Агуабланка объясняется значительным разубоживанием руд обломками безрудных магматических пород, в том числе ультраосновного состава. Для обоих месторождений характерно преобладание в рудах никеля над медью. В более богатых рудах месторождения Шануч среднее содержание никеля (5.41 \%) резко преобладает над содержанием меди (0.85 \%). В более бедных рудах месторождения Агуабланка содержание никеля $(0.66 \%)$ лишь ненамного превышает содержание меди (0.46\%).

Благородные металлы и золото находятся в рудах обоих месторождений в небольших количествах. На месторождении Агуабланка содержание МПГ - 0.47 г/т, Au - 0.13 г/т. Руды месторождения Шануч содержат, г/т: палладия -0.41 , платины -0.13 и золота -0.24 . Большая часть МПГ встречена в массивной руде в магматических сульфидах (пентландите, пирротине, реже в халькопирите), иногда на контактах между минералами. Распределение МПГ в сульфидах крайне неравномерное в виде собственных минералов.

Для главных рудных минералов характерно постоянное присутствие следующих примесей: $\mathrm{Ni}$ - для пирротинов (Шануч - до 2.77 мас. \%, Агуабланка - до 0.81 мас. \%) и пиритов (Шануч до 2.95 мас. \%, Агуабланка - до 2.81 мас. \%); Со для пентландитов (Шануч - до 1.17 мас. \%, Агуабланка - до 0.71 мас. \%) и пиритов (Шануч - до 1.5 мас. \%, Агуабланка - до 0.45 мас. \%). В халькопиритах поздних генераций установлена примесь 
висмута, теллура. В рудах обоих месторождений выделено несколько типов пирита, различающихся по морфологии, содержанию никеля и кобальта.

Текстурные, структурные, минералогические и геохимические характеристики, разнообразие морфологических разновидностей сульфидных минералов в медно-никелевых с платиноидами рудах месторождений Шануч и Агуабланка свидетельствуют о сложном эволюционном процессе их формирования. Выделяются: магматическая стадия, когда руды формировались в результате кристаллизации из сульфидно-силикатных расплавов, и постмагматическое замещение ранее образованных сульфидов, их перекристаллизация, изменение вмещающих пород при воздействии гидротермальных растворов. В магматическую стадию (пентландит-пирротиновую, халькопиритпентландит-пирротиновую) отлагались основные медно-никелевые минералы: пирротин, пентландит и халькопирит с сопутствующей минерализацией сульфоарсенидов и платиноидами преимущественно платиновой и иридиевой групп (сперрилит, ирарсит). С более поздней стадией связана теллуридно-висмутовая и золотоносная минерализации. В пострудную стадию в зоне окисления формировалась «железная шляпа».

\section{ВЫВОДЫ}

Исследование закономерностей размещения, состава руд и генезиса двух сульфидных медноникелевых месторождений, приуроченных к срединным массивам - Агуабланка (Иберийский массив, Испания) и Шануч (Камчатский массив, Россия) и сформированных в разные геологические эпохи (Агуабланка в раннем карбоне, Шануч в эоцене), показало, что они имеют ряд общих особенностей:

месторождения пространственно и генетически связаны с малыми интрузиями и дайками преимущественно основного состава;

для них характерна субвертикальная ориентировка рудных тел и их значительная протяженность на глубину, своеобразна и форма рудных тел от воронкообразной до линзовидной, штокои жилообразной;

сульфидные медно-никелевые руды как богатые, так и относительно бедные с преобладанием никеля над медью, текстура руд преимущественно брекчиевая или массивная, реже вкрапленная;

качественный состав рудных минералов обычен для сульфидных медно-никелевых месторождений. Это главным образом пирротин, пентландит и халькопирит; отмечается незначительная примесь минералов элементов платиновой группы и золота; в зоне окисления располагается «железная шляпа», являющаяся основным признаком медно-никелевого оруденения на глубине. При окислении наблюдается более активное выщелачивание никеля и кобальта по сравнению с медью, а также значительное обогащение примесью МПГ и золота.

Изучение геолого-генетических особенностей руд месторождений Агуабланка и Шануч, сформированных в разные эпохи (в палеозое и кайнозое соответственно) на различных срединных массивах (Иберийском и Камчатском), представляет научный интерес и является основой для прогнозирования новых аналогичных месторождений в этих и других регионах.

\section{ЛИТЕРАТУРА}

Вильданова Е. Ю., Зайцев В. П., Кравченко Л. И. Коряко-Камчатский район - новая платиноносная провинция России. Санкт-Петербург : ВСЕГЕИ, 2002. 383 c.

Виноградов В. И., Григорьев В. С. Rb-Sr возраст пород Срединного выступа Камчатки // ДАН. 1994. T. 339, № 5. С. 645-649.

Кунгурова В. Е., Трухин Ю. П., Алискеров А. А. Структурно-текстурные и минералогические особенности зоны окисления рудного тела № 1 месторождения Шануч (Камчатка) // Горно-информационный аналитический бюллетень. Спец. выпуск № 31 . Камчатка-3. 2016. № 11. С. 56-71.

Некрасов Е. Г. Тектоническая природа КамчатскоКорякского региона и вопросы геодинамики складчатого обрамления севера Тихого океана // Геотектоника. 2003. № 6. С. 53-79.

Полетаев $B . \quad A$. Сульфидные платиноидномедно-никелевые месторождения и рудопроявления перидотит-пироксенит-норитовой формации Центральной Камчатки // Платина России. Москва : ЗАО Геоинформмарк, 1999. Т. 3. Кн. 2. С. 191-199.

Селянгин О. Б. К сравнительной петрологии интрузивов северной и южной зон Камчатской никеленосной провинции. Часть первая // Вестник КРАУНЦ. Науки о Земле. 2014. № 1. Вып. № 23. С. 168-185.

Селянгин О. Б. О тектонической позиции никеленосных интрузивов Срединно-Камчатского массива // Вестник КРАУНЦ. Науки о Земле. 2009. № 13. C. 123-138.

Степанов В. А., Трухин Ю. П. О возрасте Шанучского медно-никелевого месторождения // ДАН. 2007. T. 417, № 1. C. 84-86.

Степанов В. А., Гвоздев В. И., Трухин Ю. П., Кунгурова B. E. Минералы благородных и редких металлов в рудах Шанучского медно-никелевого месторождения // Записки РМО. 2010. № 139 (2). С. 43-58.

Тарарин И. А. Эволюция метаморфических процессов в Срединнокамчатском массиве // Эволюция геологических процессов Дальнего Востока. Владивосток : ДВНЦ АН СССР, 1986. С. 47-61.

Трухин Ю. П., Степанов В. А., Сидоров М. Д. Камчатская никеленосная провинция // ДАН. 2008. Т. 418, № 6. C. 802-805. 
Трухин Ю. П., Степанов В. А., Сидоров М. Д., Кунгурова $B$. Е. Шанучское медно-никелевое месторождение: геолого-геофизическая модель, состав и геохимия руд // Руды и металлы. 2009. № 5. С. 75-81.

Ханчук А. И. Геология и происхождение Срединнокамчатского кристаллического массива // Тихоокеанская геология. 1983. № 4. С. 45-53.

Щеглов А. Д. Металлогения срединных массивов. Ленинград : Недра, 1971. 148 с.

Яншин А. Л. Проблема срединных массивов // Бюл. МОИП. Сер. геол. 1965. Т. 40, № 5. С. 8.

Ortega L., Lunar R., García P. F., García-Palomero F., Moreno T., Martín-Estévez J. R., Prichard H. M., Fisher $P$. C. The Aguablanca Ni - Cu - PGE deposit, southwestern Iberia: magmatic ore-forming processes and retrograde evolution // The Canadian Mineralogist. 2004. 42. P. $325-350$.
Pina R., Lunar R., Ortega L., Gervilla F., Alapieti $T$., Martínez $C$. Petrology and geochemistry of maficultramafic fragments from the Aguablanca (SW Spain) $\mathrm{Ni}-\mathrm{Cu}$ ore breccia: Implications for the genesis of the deposit // Economic Geology. 2006. 101, 865881.

Romeo I., Lunar R., Capote R., Dunning G., Dunning G., Quesada R., Dunning C., Piña G. R., Ortega L. Ages of U-Pb crystallization in zircons of the igneous complex of Santa Olalla de Cala: implications in the age of the Ni-Cu - EGP deposit in Aguablanca (Badajoz) // MACLA. 2004. 2. 29-30.

Tornos F., Iriondo A., Casquet C., Galindo C. Ar-Ar geochronology of flogopites from the Aguablanca (Badajoz) stock. Implications on the age of pluton and the associated $\mathrm{Ni}-(\mathrm{Cu})$ mineralization // Geotemas. 2004. 6. 189192.

Поступила в редакичю 15.04.2021 2.

Поступила после доработки 23.04.2021 2.

\title{
SULFIDE COPPER-NICKEL DEPOSITS IN MIDDLE MASSIFS OF THE PYRENEAN PENINSULA AND KAMCHATKA PENINSULA
}

\author{
V. A. Stepanov, V. Ye. Kungurova
}

\author{
Research Geotechnological Center, FEB RAS, Petropavlovsk-Kamchatsky
}

\begin{abstract}
A comparative description of two sulfide copper-nickel deposits confined to the middle massifs is given: Aguablanca (Iberian Massif, Spain) and Shanuch (Kamchatka Massif, Russia). It was shown that both deposits are spatially and genetically related to small intrusions and dikes of mostly basic composition. Ore bodies are funnel-shaped, lenticular, stock-shaped, and vein-like, and are spread to significant depths. Both deposits contain rich sulfide copper-nickel ores as well as relatively poor; the ore texture is predominantly breccia or massive, seldom disseminated. Ore mineral composition includes pyrrhotite, pentlandite, and chalcopyrite with an insignificant admixture of minerals of the platinum group elements and gold. The ore bodies were topped with an "iron hat", which was the main sign of copper-nickel mineralization at depth.
\end{abstract}

Keywords: Aguablanca deposits, Shanuch, sulfide copper-nickel ores, platinoids, gold, mafiteultramafites.

\section{REFERENCES}

Khanchuk, A. I., 1983. Geology and Origin of the Middle-Kamchatka Crystalline Rock Mass, Russian Journal of Pacific Geology. 4, 45-53 [In Russian].

Kungurova, V. Ye., Trukhin, Yu. P., Aliskerov, A. A., 2016. Structural, Textural, and Mineralogical Features of the Oxidation Zone of Orebody No. 1 at the Shanuch Deposit (Kamchatka), Mining and Information Analytical Bulletin. Special Issue 31. "Kamchatka-3". 11, 56-71 [In Russian].

Nekrasov, E. G., 2003. Tectonic Nature of the Kamchatka-Koryak Region and Issues of Geodynamics of the Folded Frame in the North Pacific Rim, Geotectonics. 6, 53-79 [In Russian].

Ortega, L., Lunar, R., García, P. F., García-Palomero, F., Moreno, T., Martín-Estévez, J. R., Prichard, H. M., Fisher, P. C., 2004. The Aguablanca Ni - Cu - PGE Deposit, Southwestern Iberia: Magmatic Ore-Forming Pro- cesses and Retrograde Evolution, The Canadian Mineralogist. 42, 325-350.

Pina, R., Lunar, R., Ortega, L., Gervilla, F., Alapieti, T., Martínez, C., 2006. Petrology and Geochemistry of Mafic-Ultramafic Fragments from the Aguablanca (SW Spain) Ni - Cu Ore Breccia: Implications for the Genesis of the Deposit, Economic Geology. 101, 865-881.

Poletaev, V. A., 1999. Sulfide Flatinoid-Copper-Nickel Deposits and Ore Occurrences of the Peridotite-Pyroxenite-Norite Formation in Central Kamchatka, Russia's Platinum. Moscow, ZAO Geoinformmark. Vol. 3, Book 2. 191-199 [In Russian].

Romeo, I., Lunar, R., Capote, R., Dunning, G., Quesada, R., Dunning, C., Piña, G. R., Ortega, L., 2004. Ages of U-Pb Crystallization in Zircons of the Igneous Complex of Santa Olalla de Cala: Implications in the Age of the $\mathrm{Ni}-\mathrm{Cu}-$ EGP Deposit in Aguablanca (Badajoz), MACLA. 2, 29-30. 
Scheglov, A. D., 1971. Median Massif Metallogeny. Leningrad, Nedra [In Russian].

Selyangin, O. B., 2009. On the Tectonic Position of Nickel-Bearing Intrusives of the Middle Kamchatka Massif, Bulletin of Kamchatka Regional Association "Educational-Scientific Center”. Earth Sciences. 13, 123-138 [In Russian].

Selyangin, O. B., 2014. On Comparative Petrology of Intrusions in the Northern and Southern Zones of the Kamchatka Nickel-Bearing Province. Part I. Bulletin of Kamchatka Regional Association "Educational-Scientific Center”. Earth Sciences. 1 (23), 168-185 [In Russian].

Stepanov, V. A., Gvozdev, V. I., Trukhin, Yu. P., Kungurova, V. Ye., 2010. Minerals of Precious and Rare Metals in the Ores of the Shanuchskoye Copper-Nickel Deposit (Kamchatka), Zapiski RMO. 139 (2), 43-58 [In Russian].

Stepanov, V. A., Trukhin, Yu. P., 2007. Age of the Shanuch Copper-Cickel Deposit in Kamchatka, Doklady Akademiyi Nauk. 417 (1), 1193-1194.

Tararin, I. A., 1986. Evolution of Metamorphic Processes in the Middle-Kamchatka Massif. Evolution of Geological Processes in the Far East. Vladivostok, DVNC AN USSR. 47-61 [In Russian].
Tornos, F., Iriondo, A., Casquet, C., Galindo, C., 2004. Ar-Ar Geochronology of Flogopites from the Aguablanca (Badajoz) Stock. Implications on the Age of Pluton and the Associated $\mathrm{Ni}-(\mathrm{Cu})$ Mineralization. Geotemas. 6, 189-192.

Trukhin, Yu. P., Stepanov, V. A., Sidorov, M. D., 2008. Kamchatka Nickel-Bearing Province, Doklady Akademiyi Nauk. 419 (1), 214-216.

Trukhin, Yu. P., Stepanov, V. A., Sidorov, M. D., Kungurova, V. Ye., 2009. The Shanuch Copper-Nickel Deposit: Geological and Geophysical Model, Composition and Geochemistry of Ores, Ores and Metals. 5, 75-81 [In Russian].

Vildanova, E. Yu., Zaitsev, V. P., Kravchenko, L. I., 2002. Koryak-Kamchatka District: New Platinum-Bearing Province of Russia. St. Petersburg, VSEGEI [In Russian].

Vinogradov, V. I., Grigoryev, V. S., 1994. Rb-Sr Age of Rocks of Kamchatka's Middle Protrusion, Doklady Akademiyi Nauk. 339 (5), 645-649 [In Russian].

Yanshin, A. L., 1965. Problem of Middle Massifs, Bulletin of Moscow Society of Naturalists, Geological Series. 40 (5), 8 [In Russian]. 